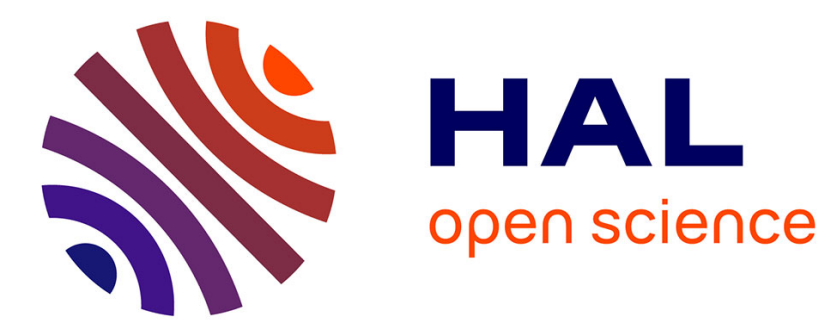

\title{
Protective effect of Artemisia campestris extract against aspirin-induced gastric lesions and oxidative stress in rat
} Hichem Sebai, Mohamed-Amine Jabri, Abdelaziz Souli, Karim Hosni, Slimen

Selmi, Haifa Tounsi, Olfa Tebourbi, Samir Boubaker, Jamel El-Benna, Mohsen Sakly

\section{To cite this version:}

Hichem Sebai, Mohamed-Amine Jabri, Abdelaziz Souli, Karim Hosni, Slimen Selmi, et al.. Protective effect of Artemisia campestris extract against aspirin-induced gastric lesions and oxidative stress in rat. RSC Advances, 2014, 4 (91), pp.49831 - 49841. 10.1039/c4ra08564g · pasteur-01375101

\section{HAL Id: pasteur-01375101 \\ https://hal-riip.archives-ouvertes.fr/pasteur-01375101}

Submitted on 3 Oct 2017

HAL is a multi-disciplinary open access archive for the deposit and dissemination of scientific research documents, whether they are published or not. The documents may come from teaching and research institutions in France or abroad, or from public or private research centers.
L'archive ouverte pluridisciplinaire HAL, est destinée au dépôt et à la diffusion de documents scientifiques de niveau recherche, publiés ou non, émanant des établissements d'enseignement et de recherche français ou étrangers, des laboratoires publics ou privés. 


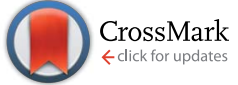

Cite this: RSC Adv., 2014, 4, 49831

Received 12th August 2014

Accepted 18th September 2014

DOI: $10.1039 / \mathrm{c} 4 \mathrm{ra0} 8564 \mathrm{~g}$

www.rsc.org/advances

\section{Protective effect of Artemisia campestris extract against aspirin-induced gastric lesions and oxidative stress in rat}

\author{
Hichem Sebai, $\uparrow^{\star a b}$ Mohamed-Amine Jabri, $\uparrow^{\mathrm{ab}}$ Abdelaziz Souli, ${ }^{\mathrm{b}}$ Karim Hosni, ${ }^{\mathrm{c}}$ \\ Slimen Selmi, ${ }^{b}$ Haifa Tounsi, ${ }^{d}$ Olfa Tebourbi, ${ }^{a}$ Samir Boubaker, ${ }^{d}$ Jamel El-Benna ${ }^{e}$ \\ and Mohsen Sakly ${ }^{a}$
}

The present study aims at evaluating the antiulcer and antioxidant effect of Artemisia campestris aqueous extract (ACAE) as well as the mechanism of action involved in such gastroprotection. The use of LC/MS allowed the identification of 11 phenolic compounds and the colorimetric analysis demonstrated that the ACAE exhibited an important in vitro antioxidant activity. We first showed that in vivo ACAE protected against macroscopic and histological changes induced by aspirin in stomach mucosa. Aspirin administration was accompanied by an oxidative stress status assessed by an increase in malondialdehyde (MDA) level, a decrease in the content of sulfhydryl -(SH) groups and a depletion of antioxidant enzyme activities such as superoxide dismutase (SOD), catalase (CAT) and glutathione peroxidase (GPX). Pre-treatment with ACAE protected against aspirin-induced gastric oxidative stress. More importantly, aspirin administration increased plasma and tissue hydrogen peroxide $\left(\mathrm{H}_{2} \mathrm{O}_{2}\right)$, free iron and calcium levels, while the ACAE pre-treatment reversed all the effects of aspirin-induced intracellular mediators. In conclusion, we suggest that Artemisia campestris aqueous extract has potent antiulcer and antioxidant properties. This gastroprotection offered by ACAE might be related partly to the safety of sulfhydryl group as well as its opposite effect on some intracellular mediators such as hydrogen peroxide, free iron and calcium.

\section{Introduction}

Ulcer is a multifactorial gastrointestinal disorder caused by the loss of balance between aggressive and defensive factors of the gastric and duodenal mucosa. ${ }^{1}$ The nonsteroidal antiinflammatory drugs (NSAIDs), Helicobacter pylori, stress, and steroids, are the aggressive factors that increase the risk of gastric ulcer formation..$^{2-4}$ NSAIDs are widely used for their analgesic, anti-pyretic and anti-inflammatory effects. ${ }^{5,6}$ However, these drugs are in fact associated with gastrointestinal toxicity including ulcer formation. ${ }^{6,7}$ The pathogenesis of NSAIDs-induced gastric ulceration is accompanied by lower mucus and bicarbonate secretion, decreased mucosal blood flow, neutrophil infiltration, alteration

${ }^{a}$ Laboratoire de Physiologie Intégrée, Faculté des Sciences de Bizerte, Département des Sciences de la Vie, 7021 Zarzouna, Tunisia. E-mail: sebaihichem@yahoo.fr; Fax: +216 72590 566; Tel: +21697249486

${ }^{b}$ Laboratoire de Nutrition et Physiologie Animale - Institut Supérieur de Biotechnologie de Béja, Avenue Habib Bourguiba - B.P. 382 - 9000, Béja, Tunisia

${ }^{c}$ Laboratoire des Substances Naturelles, Institut National de Recherche et d'Analyse Physico-chimique, Sidi Thabet, 2020 Ariana, Tunisia

${ }^{d}$ Laboratoire d'anatomie Pathologique Humaine et Expérimentale, Institut Pasteur de Tunis, 13, Place Pasteur, BP-74, Tunis 1002, Tunisia

${ }^{e}$ INSERM U773 Centre de Recherche Biomédicale - Faculté de Médecine X, Bichat 75018, Paris, France

$\dagger$ The first two authors contributed equally to this work. of microvascular structures, and increased acid and pepsinogen secretion. ${ }^{\mathbf{8} 9}$ In addition, the pathogenesis of NSAIDs-induced ulcers, such as aspirin, is also accompanied by an increase in reactive oxygen species (ROS). ${ }^{10}$ These in turn induce lipid peroxidation and antioxidant enzymes inhibition, which are the basis of many toxicological and pathological processes. ${ }^{\mathbf{1 1}}$ However, plant extracts, known for their richness in phenolic compounds and antioxidant ability, are mainly used by researchers to produce new drugs and obtain promising results in the treatment of gastric ulcers. ${ }^{12}$

Artemisia campestris L. is a medicinal plant used for centuries in traditional folk medicine in many countries in the world including Tunisia, and is well-known for its beneficial effects in the treatment of gastrointestinal disorders, including peptic ulcer. ${ }^{13}$ In addition, this plant is well-known as a versatile source of components with bioactive properties. Because of its antioxidant properties, ${ }^{\mathbf{1 4}}$ A. campestris presents many beneficial health effects such as hepatoprotective, ${ }^{\mathbf{1 5}}$ renoprotective, ${ }^{\mathbf{1 4}}$ antidiabetic $^{16}$ and anticancer ${ }^{13}$ activities. Recently, Houicher et $a{ }^{17}{ }^{17}$ demonstrated that ethanolic extract obtained from $A$. campestris prevents food spoilage and extends the shelf life of vacuum-packed refrigerated sardines (Sardina pilchardus).

The aim of the present study is to evaluate the antioxidant properties of an aqueous extract of $A$. campestris as well as its protective effect against aspirin-induced gastric ulceration in 
rats. We also study the implication of sulfhydryl groups and some intracellular mediators in such gastroprotection.

\section{Materials and methods}

\subsection{Chemicals}

Epinephrine, bovine catalase, 2-thio-barbituric acid (TBA) and butylated hydroxytoluene (BHT) were purchased from Sigma chemicals Co (Germany). All the other chemicals used were of analytical grade.

\subsection{Preparation of Artemisia campestris aqueous extract}

Artemisia campestris plants were cultivated in the region of Metlaoui (South-western Tunisia) during August 2012 and were identified by Mrs Mouhiba Ben-Naceur, Professor of taxonomy in the Higher Institute of Biotechnology of Béja - Tunisia. Plant material was subsequently dried in an incubator at $50{ }^{\circ} \mathrm{C}$ for 72 hours and powdered in an electric blender. The extract was prepared in double distilled water $(1 / 5 ; \mathrm{w} / \mathrm{v})$ under magnetic agitation for 24 hours and centrifuged at $10000 \mathrm{~g}$ for $10 \mathrm{~min}$ to eliminate insoluble material. Supernatant was lyophilised and stored at $-80{ }^{\circ} \mathrm{C}$ until use.

\subsection{Characterisation of phenolic compounds by HPLC-PDA- ESI-MS/MS}

The lyophilised extract of A. campestris $\left(1 \mathrm{mg} \mathrm{mL}^{-1}\right)$ was dissolved in methanol ${ }^{18}$ and analyzed by LC-MS/MS using an Agilent Series 1100 LC system (Agilent Technologies, Palo Alto, Ca, USA) equipped with a photodiode array detector (PDA) and a triple quadrupole mass spectrometer type Micromass Autospec Ultima Pt (Kelso, UK) interfaced with an ESI ion source. Separation was achieved using a Superspher ${ }^{\circledR} 100(12.5 \mathrm{~cm} \times 2 \mathrm{~mm}$ i.d., $4 \mu \mathrm{m}$, Agilent Technologies, Rising Sun, MD) at $45{ }^{\circ} \mathrm{C}$. Samples $(20 \mu \mathrm{L})$ were eluted through the column with a gradient mobile phase consisting of A $(0.1 \%$ acetic acid) and B (aceto-

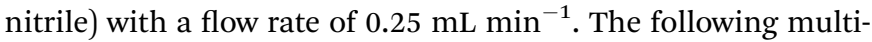
step linear solvent gradient was employed: 0-5 min, 2\% B, 5-75 $\min , 88 \% \mathrm{~B}, 75.1-90 \mathrm{~min}, 2 \% \mathrm{~B}$.

PDA was detected in the $200-400 \mathrm{~nm}$ wavelength range and the mass spectra were recorded in negative ion mode under the following operating conditions: capillary voltage, $3.2 \mathrm{kV}$; cone voltage, $115 \mathrm{~V}$; probe temperature, $350{ }^{\circ} \mathrm{C}$; ion source temperature, $110{ }^{\circ} \mathrm{C}$. The spectra were acquired in an $\mathrm{m} / \mathrm{z}$ range of 150-750 amu.

The identification of phenolic compounds was based on cochromatography with authentic standards, when available. PDA and mass spectra were used to affirm the identity of compounds previously reported in the literature. ${ }^{19-21}$ The content percentage of each component in the crude extract was determined by a UV chromatogram at $210 \mathrm{~nm} .^{18}$

\subsection{Free radical-scavenging activity on 2,2-diphenyl-1- picrylhydrazyl (DPPH)}

The antioxidant capacity of CDE was determined using DPPH radical-scavenging activity, as previously described by Grzegorczyk et al. ${ }^{22}$ Briefly, various concentrations of ACAE (20, 50,
100,150 , and $200 \mu \mathrm{g} \mathrm{mL} \mathrm{m}^{-1}$ ) were added to $1 \mathrm{~mL}$ of a $0.1 \mathrm{mM}$ methanol solution of DPPH and incubated at $27^{\circ} \mathrm{C}$ for $30 \mathrm{~min}$. The optical density of the sample was quantified at $517 \mathrm{~nm}$. DPPH radical-scavenging activity (RSA), expressed as percentage, was estimated by the following formula:

$$
\operatorname{RSA}(\%)=\frac{A_{\mathrm{DPPH}}-\left(A_{\text {sample }}-A_{\text {control }}\right)}{A_{\mathrm{DPPH}}} \times 100
$$

Ascorbic acid in the same concentration as the test extract was used as a reference molecule.

All the analyses were executed in triplicate. The efficacy concentration 50 (EC50) value was determined as the concentration (in $\mu \mathrm{g} \mathrm{mL}^{-1}$ ) of the compound required to scavenge $50 \%$ of the DPPH radical.

\subsection{Animals and treatment}

Adult male Wistar rats (weighing 200-220 g; housed five per cage) and adult male Swiss Albino mice (weighing approximately $25 \mathrm{~g}$; housed ten per cage) were purchased from the Pasteur Institute of Tunis and were used in accordance with the local ethics committee of Tunis University for the use and care of animals in accordance with the NIH recommendations. The rats were provided with food (standard pellet diet, Badr UtiqueTN) and water ad libitum and were maintained in an animal house at controlled temperature $\left(22 \pm 2{ }^{\circ} \mathrm{C}\right)$ with a 12 hours light-dark cycle. The rats were divided into seven groups of 10 animals each. Groups 1 and 2 served as controls and had bidistilled water ( $5 \mathrm{~mL} \mathrm{~kg}^{-1}$, b.w., p.o.). Groups 3, 4, and 5 were pre-treated with various doses of ACAE (100, 200 and $400 \mathrm{mg}$ $\mathrm{kg}^{-1}$, b.w. p.o.), while groups 6 and 7 were pre-treated with famotidine (20 $\mathrm{mg} \mathrm{kg}^{-1}$, b.w. p.o.) and caffeic acid $\left(50 \mathrm{mg} \mathrm{kg}^{-1}\right.$, b.w. p.o.), respectively. Rats were fasted for $24 \mathrm{~h}$ prior to the administration of ACAE or reference molecules.

After $60 \mathrm{~min}$, each animal, except group 1, received aspirin (300 $\mathrm{mg} \mathrm{kg}^{-1}$, b.w.) by oral administration. Two hours later, rats were sacrificed. Blood was collected in heparinized tubes. After centrifugation at $3000 \mathrm{~g}$ for $15 \mathrm{~min}$, free iron, $\mathrm{H}_{2} \mathrm{O}_{2}$ and calcium were determined from free plasma.

\subsection{Acute toxicity study}

A. campestris aqueous extract in the dose range of 12.5, 25, 50, $100,200,400,800,1600$ and $3200 \mathrm{mg} \mathrm{kg}^{-1}$ was orally administrated to different groups of mice $(n=10)$. Animals were examined every $30 \mathrm{~min}$ for $4 \mathrm{~h}$ and then occasionally for an additional period of $8 \mathrm{~h}$. After $24 \mathrm{~h}$, the mortality was recorded. The mice were also observed for other signs of toxicity such as motor co-ordination, righting reflex and respiratory changes.

\subsection{Evaluation of gastric mucosal damage}

The stomach of each animal was removed and opened along its greater curvature. The tissue was gently rinsed with $0.9 \% \mathrm{NaCl}$. The lesions in the gastric mucosa were macroscopically examined, and the photographs of hemorrhagic erosions were acquired with a Photometrics Quantix digital camera. Ulcer indexes were determined as the sum of the lengths of the entire 
gastric lesions (in $\mathrm{mm}^{2}$ ). Two independent, blinded observers performed the measurements of lesion lengths.

\subsection{Stomach mucosa preparation}

After the macroscopic analyses, the stomach mucosa was rapidly excised and homogenized in phosphate buffer saline $\left(\mathrm{KH}_{2} \mathrm{PO}_{4} / \mathrm{K}_{2} \mathrm{HPO}_{4}, 50 \mathrm{mM}\right.$, pH 7.4$)$ with Potter-Elvehjem homogenizer. After centrifugation at $10000 \mathrm{~g}$ for $10 \mathrm{~min}$ at $4{ }^{\circ} \mathrm{C}$, supernatant was used for the biochemical determination of protein, free iron, $\mathrm{H}_{2} \mathrm{O}_{2}$, calcium, $\mathrm{SH}-$ groups, MDA and antioxidant enzyme activities.

\subsection{Histopathological analysis}

Immediately after sacrifice, small pieces of stomach were harvested and washed with ice cold saline. Tissue fragments were then fixed in $10 \%$ neutral buffered formalin solution, embedded in paraffin and used for histopathological examination. $5 \mu \mathrm{m}$ thick sections were cut, deparaffinized, hydrated and stained with hematoxylin and eosin (HE). The gastric sections were examined in blind fashion for all the treatments.

\subsection{Lipid peroxidation measurement}

Gastric mucosa lipid peroxidation was determined by MDA measurement according to the double heating method. ${ }^{23}$ Briefly, aliquots from gastric mucosa homogenates were mixed with BHT-TCA solution containing 1\% BHT (w/v) dissolved in $20 \%$ TCA $(\mathrm{w} / \mathrm{v})$ and centrifuged at $1000 \mathrm{~g}$ for $5 \mathrm{~min}$ at $4{ }^{\circ} \mathrm{C}$. Supernatant was blended with solution containing $(0.5 \mathrm{~N} \mathrm{HCl}$ $120 \mathrm{mM}$ TBA in $26 \mathrm{mM}$ Tris) and then heated at $80^{\circ} \mathrm{C}$ for during $10 \mathrm{~min}$. After cooling, the absorbance of the resulting chromophore was determined at $532 \mathrm{~nm}$ using a UV-visible spectrophotometer (Beckman DU 640B). MDA levels were determined by using an extinction coefficient for MDA-TBA complex of $1.56 \times 10^{5} \mathrm{M}^{-1} \mathrm{~cm}^{-1}$.

\subsection{Antioxidant enzyme activity assays}

SOD activity was determined using modified epinephrine assays. ${ }^{24}$ At alkaline $\mathrm{pH}$, superoxide anion $\mathrm{O}_{2}{ }^{-}$causes the autoxidation of epinephrine to adenochrome; while competing with this reaction, SOD decreased the adenochrome formation. One unit of SOD is defined as the amount of extract that inhibits the rate of adenochrome formation by $50 \%$. Enzyme extract was added in $2 \mathrm{~mL}$ reaction mixture containing $10 \mu \mathrm{L}$ of bovine

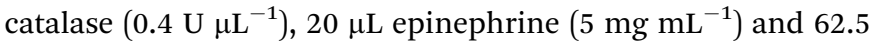
$\mathrm{mM}$ sodium carbonate/bicarbonate buffer of $\mathrm{pH} 10.2$. Changes in absorbance were recorded at $480 \mathrm{~nm}$.

CAT activity was assessed by measuring the initial rate of $\mathrm{H}_{2} \mathrm{O}_{2}$ disappearance at $240 \mathrm{~nm} .{ }^{25}$ The reaction mix contained 33 $\mathrm{mM} \mathrm{H}_{2} \mathrm{O}_{2}$ in $50 \mathrm{mM}$ phosphate buffer at $\mathrm{pH}$ 7.0, and the activity of CAT was calculated using the extinction coefficient of $40 \mathrm{mM}^{-1} \mathrm{~cm}^{-1}$ for $\mathrm{H}_{2} \mathrm{O}_{2}$.

GPx activity was quantified by the procedure reported by Flohé and Günzler. ${ }^{26}$ Briefly, $1 \mathrm{~mL}$ of the reaction mixture containing $0.2 \mathrm{~mL}$ of liver supernatant, $0.2 \mathrm{~mL}$ of phosphate buffer $(0.1 \mathrm{M}, \mathrm{pH}=7.4), 0.2 \mathrm{~mL}$ of $\mathrm{GSH}(4 \mathrm{mM})$ and $0.4 \mathrm{~mL}$ of
$\mathrm{H}_{2} \mathrm{O}_{2}(5 \mathrm{mM})$ was incubated at $37^{\circ} \mathrm{C}$ for $1 \mathrm{~min}$, and the reaction was stopped by adding $0.5 \mathrm{~mL}$ TCA $(5 \%, \mathrm{w} / \mathrm{v})$. After centrifugation at $1500 \mathrm{~g}$ for $5 \mathrm{~min}$, an aliquot $(0.2 \mathrm{~mL})$ from the supernatant was combined with $0.5 \mathrm{~mL}$ of phosphate buffer $(0.1 \mathrm{M}$, $\mathrm{pH}=7.4)$ and $0.5 \mathrm{~mL}$ DTNB $(10 \mathrm{mM})$, and the absorbance was determined at $412 \mathrm{~nm}$. GPx activity was expressed as nmol of GSH consumed $/ \mathrm{min} / \mathrm{mg}$ of protein.

\subsection{Thiol groups measurement}

The total concentration of thiol groups $(-\mathrm{SH})$ was performed according to the Ellman's method. ${ }^{27}$ Briefly, aliquots from stomach mucosa were mixed with $100 \mu \mathrm{L}$ of $10 \%$ SDS and 800 $\mu \mathrm{L}$ of $10 \mathrm{mM}$ phosphate buffer ( $\mathrm{pH}$ 8), and optical density was measured at $412 \mathrm{~nm}\left(A_{0}\right)$. Then, $100 \mu \mathrm{L}$ of DTNB was added and incubated at $37^{\circ} \mathrm{C}$ for $60 \mathrm{~min}$. After incubation, the absorbance of the sample was quantified at $412 \mathrm{~nm}\left(A_{1}\right)$. The concentration of thiol groups was calculated from $A_{1}$ to $A_{0}$ subtraction using a molar extinction coefficient of $13.6 \times 10^{3} \mathrm{M}^{-1} \times \mathrm{cm}^{-1}$. The results were expressed as the nmol of thiol groups per $\mathrm{mg}$ of protein.

\subsection{3. $\mathrm{H}_{2} \mathrm{O}_{2}$ determination}

The gastric mucosal $\mathrm{H}_{2} \mathrm{O}_{2}$ level was determined following Dingeon et $a .^{28}$ Briefly, hydrogen peroxide reacts with $p$-hydroxybenzoic acid and 4-aminoantipyrine in the presence of peroxidase leading to the formation of quinoneimine that has a pink color detected at $505 \mathrm{~nm}$.

\subsection{Iron measurement}

Gastric mucosa and plasma non haem iron were measured colorimetrically using ferrozine, as described by Leardi $e t$ al. ${ }^{29}$ Briefly, the iron dissociated from transferrin-iron complex by guanidine acetate solution was reduced by ascorbic acid and was reacted with ferrozine, leading to the formation of a pink complex measured at $562 \mathrm{~nm}$.

\subsection{Calcium determination}

Gastric mucosa and plasma calcium were determined using a colorimetric method following the method reported by Stern and Lewis. ${ }^{30}$ Briefly, in alkaline medium, calcium reacted with cresolphtalein forming a colored complex detectable at $570 \mathrm{~nm}$.

\subsection{Protein determination}

Protein concentration was determined according to Hartree ${ }^{31}$ as a slight modification of the Lowry method. Serum albumin was used as a standard.

\subsection{Statistical analysis}

The data were analyzed by unpaired Student's $t$-test and were expressed as means \pm standard error of the mean (S.E.M.). The data are representative of 10 independent experiments. All the statistical tests were two-tailed, and a $p$ value of 0.05 or less was considered significant. 


\section{Results}

\subsection{HPLC-PDA-ESI-MS/MS analysis}

The maximum absorption wavelengths $\left(\lambda_{\max }\right)$, parent ion, and fragment ion masses of the components detected in the aqueous extract of $A$. campestris are shown in Table 1, where the compounds are numbered according to their retention time $\left(t_{\mathrm{R}}\right)$ in the obtained chromatograms (Fig. 1).

Overall, 11 phenolic compounds including 5 hydroxycinnamic acid derivatives, 2 glycosylated flavonols, 2 glycosylated flavones, 1 flavonol aglycone and 1 flavone aglycone were identified.

The identification of hydroxycinnamic acids was based on UV-DAD spectra conjugated with the MS fragmentation data, and their retention time was compared with those of the authentic standards, when available. Consequently, peak $1\left(t_{\mathrm{R}}=\right.$ $16.5 \mathrm{~min}$ ) was identified as chlorogenic acid (3-O-caffeoylquinic acid). It showed UV absorption maxima at $325 \mathrm{~nm}$ with a shoulder at 290-300 $\mathrm{nm}$ and exhibited deprotonated molecular ion at $m / z 353$ with the main MS $^{2}$ fragment at $m / z 191$ and 179, indicating that the caffeoyl group is linked to the $3-\mathrm{OH}$ position of quinic acid. ${ }^{\mathbf{1 9}}$ The identity of this compound was confirmed by comparing its UV and $\mathrm{MS}^{2}$ spectra and HPLC retention time with the standard chlorogenic acid. Peak $2\left(t_{\mathrm{R}}=17.2 \mathrm{~min} ; \lambda_{\max }\right.$ $323 \mathrm{~nm} ;[\mathrm{M}-\mathrm{H}]^{-}$at $\mathrm{m} / z$ 179) was identified as caffeic acid by comparing its UV and mass spectra and its $t_{\mathrm{R}}$ with those of a reference standard.

Peaks $4\left(t_{\mathrm{R}}=23.9 \mathrm{~min} ; \lambda_{\max } 327 \mathrm{~nm}\right), 5\left(t_{\mathrm{R}}=24.1 \mathrm{~min} ; \lambda_{\max }\right.$ $329 \mathrm{~nm})$ and $6\left(t_{\mathrm{R}}=24.6 ; \lambda_{\max } 329\right)$ displayed the same deprotonated molecular ion at $\mathrm{m} / \mathrm{z} 515$ and the $[\mathrm{M}-\mathrm{H}]^{-}$ion at $\mathrm{m} / \mathrm{z}$ 353 , indicating the loss of a caffeoyl residue. Based on the hierarchical key proposed by Clifford et al. ${ }^{19}$ and their order of elution, they were tentatively identified as 3,4-dicaffeoylquinic acid (compound 4), 3,5-dicaffeoylquinic acid (compound 5) and 4,5-dicaffeoylquinic acid (compound 6).

Peak $3\left(t_{\mathrm{R}}=21.4 \mathrm{~min} ; \lambda_{\max } 259-357 \mathrm{~nm}\right)$ showed characteristic UV absorption of flavonols and exhibited $[\mathrm{M}-\mathrm{H}]^{-}$ion at $m / z$ 477. Its $\mathrm{MS}^{2}$ spectra gave $[\mathrm{M}-\mathrm{H}-162]^{-}$ion at $\mathrm{m} / z$ at 315 , indicative of the aglycone isorhamnetin. This compound was tentatively identified as isorhamnetin hexoside. ${ }^{\mathbf{2 0}}$

Peak $7\left(t_{\mathrm{R}}=25.1 \mathrm{~min} ; \lambda_{\max } 260-359 \mathrm{~nm}\right)$ gave a $[\mathrm{M}-\mathrm{H}]^{-}$ion at $m / z 477$ and its $\mathrm{MS}^{2}$ fragmentation yielded a fragment ion at $m / z 301$ (quercetin aglycone) due to the loss of a glucuronic acid moiety (176 da). This compound was tentatively identified as quercetin-3-O-glucuronide.

Peaks $8\left(t_{\mathrm{R}}=25.7 \mathrm{~min}\right)$ and $9\left(t_{\mathrm{R}}=27.7 \mathrm{~min}\right)$ showed similar UV spectra with maximum absorbance at 267 and $337 \mathrm{~nm}$, respectively, which represented characteristic UV absorption of flavone. Compound $\mathbf{8}$ displayed a deprotonated molecular ion at $m / z 431$ and gave a fragment ion at $m / z 269$ (apigenin aglycone), suggesting the loss of hexose moiety (162 da). As it is known, the most common substitution position for flavones is the 7-OH. Therefore, compound $\mathbf{8}$ was tentatively identified as apigenin-7-O-hexoside. ${ }^{21}$ Compound 9 exhibited $[\mathrm{M}-\mathrm{H}]^{-}$ion at $\mathrm{m} / \mathrm{z} 577$ and its $\mathrm{MS}^{2}$ spectrum gave a fragment ion at $\mathrm{m} / \mathrm{z}$ $517[\mathrm{M}-\mathrm{H}-60]^{-}$, at $\mathrm{m} / \mathrm{z} 401$ (loss of glucuronic acid moiety $[\mathrm{M}-\mathrm{H}-176]^{-}$) and a fragment ion at $m / z 269$ (loss of pentose moiety [M - H-glucuronic acid-132 $]^{-}$) assigned as the aglycone apigenine. Because the fragment ion $[\mathrm{M}-\mathrm{H}-60]^{-}$had a higher intensity for C-6 glycoside than for C-8 glycoside and indicated the fragmentation of a C-pentose unit, ${ }^{19}$ it is plausible to identify compound 9 as apigenin-6- $C$-glucuronide-8- $C$-pentoside.

Peak $10\left(t_{\mathrm{R}}=30.03 \mathrm{~min}\right)$, which displayed a $[\mathrm{M}-\mathrm{H}]^{-}$ion at $m / z 285$ and had maximum UV absorbance at 253 and $347 \mathrm{~nm}$, was identified as kaempferol by comparing its UV and MS spectra and HPLC retention time with those of a reference standard.

By using the same procedure, compound $11\left(t_{\mathrm{R}}=30.03 \mathrm{~min}\right.$; $\lambda_{\max } 267-337 \mathrm{~nm}$ ) with $[\mathrm{M}-\mathrm{H}]^{-}$ion at $\mathrm{m} / z 269$ was unequivocally identified as apigenin.

\subsection{Antioxidant capacity of ACAE}

Concerning the antioxidant capacity, we found that the radicalscavenging activity of ACAE and ascorbic acid against DPPH radical increased significantly in a dose-dependant manner (Fig. 2). The EC50 values calculated from the graph demonstrated a higher rate of RSA for ACAE $\left(\right.$ EC50 $\left.=160.64 \mu \mathrm{g} \mathrm{mL}^{-1}\right)$ but lesser than that of ascorbic acid (EC50 $\left.=72.59 \mu \mathrm{g} \mathrm{mL}^{-1}\right)$, a well-known antioxidant reference molecule.

\subsection{Acute oral toxicity of CDE}

In the acute oral toxicity study, neither abnormal behavior nor mortality was detected during the observation period. Thus, the

Table 1 Characterisation of phenolic compounds of Artemisia campestris aqueous extract by HPLC-DAD-ESI-MS/MS

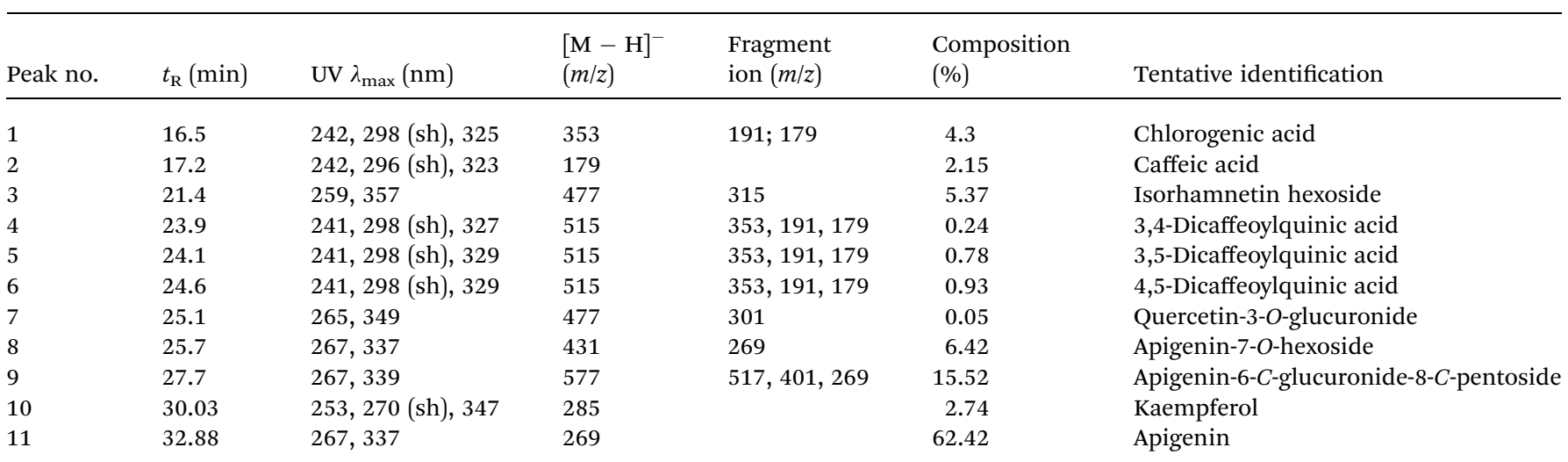


(A)

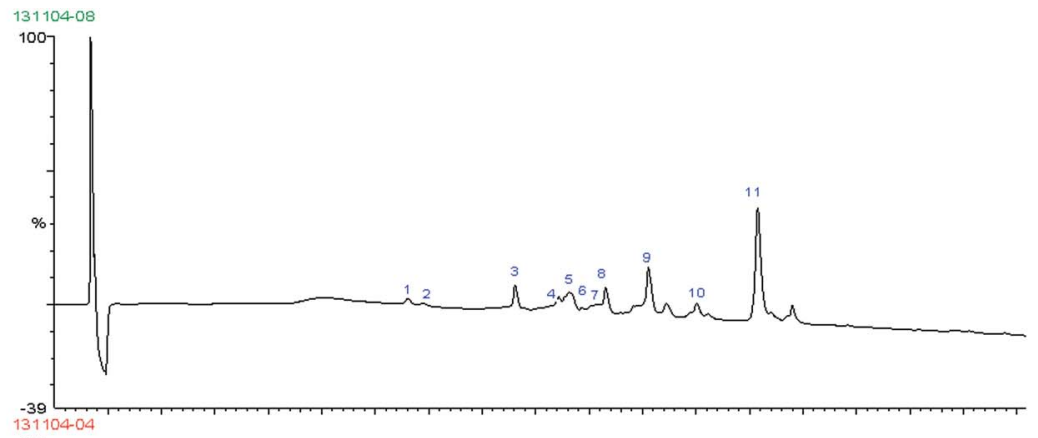

(B)

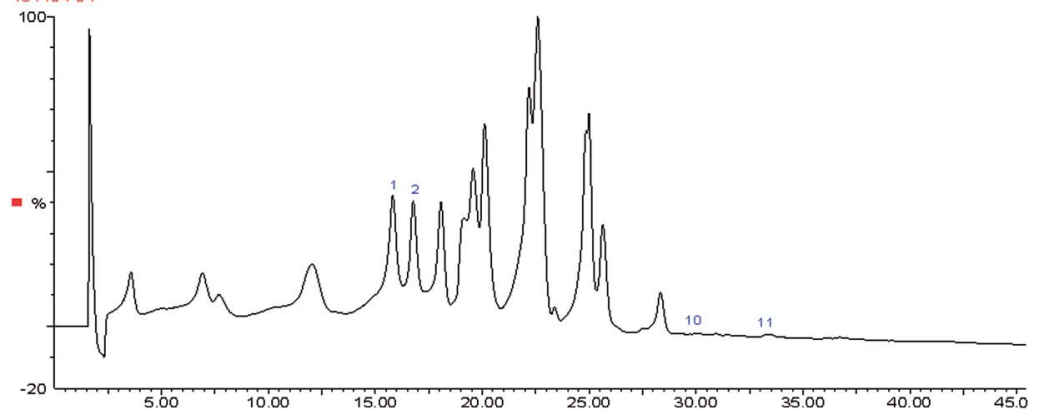

Fig. 1 HPLC-DAD chromatograms monitored at $280 \mathrm{~nm}$ of (A) Artemisia campestris aqueous extract (ACAE) and (B) standard mixture.

LD50 value was greater than $3200 \mathrm{mg} \mathrm{kg}^{-1}$ b.w. for A. campestris aqueous extract.

\subsection{Effect of ACAE on aspirin-induced acute macroscopic gastric injury}

The macroscopic examination of gastric mucosa showed that aspirin administration exhibited injuries, including hemorrhage and hyperemia. ACAE, famotidine and caffeic acid treatment showed a dose dependant decrease in all the macrospical

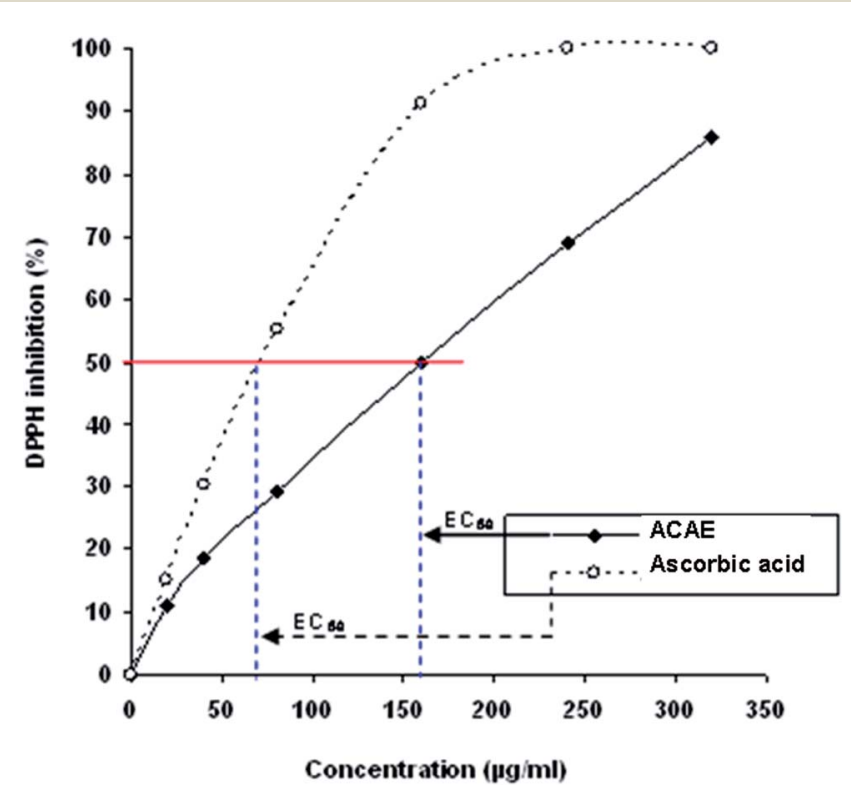

Fig. 2 Free radical-scavenging activity of the Artemisia campestris aqueous extract (ACAE) and ascorbic acid on 2,2-diphenyl-1-picrylhydrazyl (DPPH).

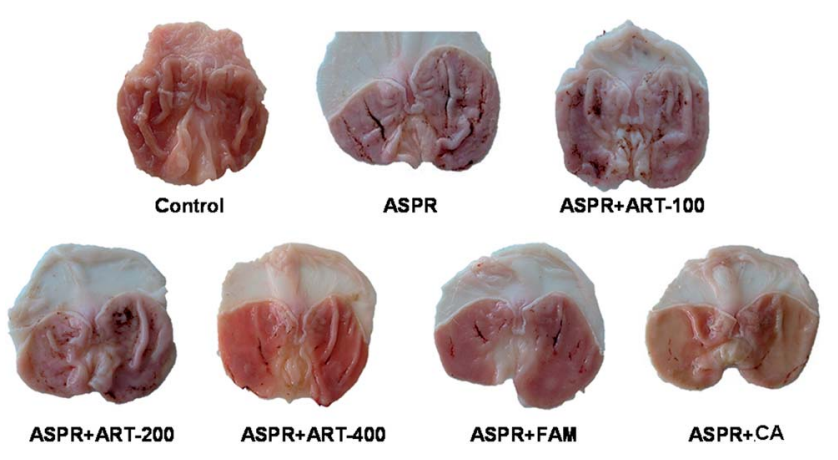

Fig. 3 Subacute effect of Artemisia campestris aqueous extract (ACAE), famotidine and caffeic acid on macroscopic changes induced by aspirin in rats. Animals were pre-treated with various doses of ACAE (100, 200 and $400 \mathrm{mg} \mathrm{kg}^{-1}$, b.w., p.o.), famotidine $\left(20 \mathrm{mg} \mathrm{kg}^{-1}\right.$, b.w., p.o.), caffeic acid (50 mg kg-1, b.w., p.o.) or bi-distilled water, challenged with a single oral administration of aspirin $\left(300 \mathrm{mg} \mathrm{kg}^{-1}\right.$, b.w., p.o.) or $\mathrm{NaCl}(9 \%)$ for one hour.

toxic signs compared with the aspirin treated group (Fig. 3). Moreover, quantitative analysis showed that pre-treatment with Artemisia campestris or reference molecules significantly and dose-dependently reduced the ulcer index and ameliorated the protection of injury induced by aspirin administration (Table 2).

\subsection{Effect of ACAE on aspirin-induced acute histopathological gastric injury}

Histological observation demonstrated that gastric mucosa of rats pre-treated with $\mathrm{H}_{2} \mathrm{O}$ and intoxicated with aspirin at $300 \mathrm{mg}$ $\mathrm{kg}^{-1}$ showed marked erosive lesions in the gastric tissue. ACAE, famotidine and caffeic acid pre-treatment significantly reduced the structural changes induced by aspirin intoxication (Fig. 4). 
Table 2 Subacute effect of Artemisia campestris aqueous extract (ACAE), famotidine and caffeic acid on macroscopic changes induced by aspirin in rats: ulcer index and inhibition percentage. Animals were pre-treated with various doses of ACAE $\left(100,200\right.$ and 400 mg kg ${ }^{-1}$, b.w., p.o.), famotidine (20 mg kg $\mathrm{mg}^{-1}$, b.w., p.o.), caffeic acid $\left(50 \mathrm{mg} \mathrm{kg}^{-1}\right.$, b.w., p.o.) or bi-distilled water, and they were challenged with a single oral administration of aspirin (300 $\mathrm{mg} \mathrm{kg}^{-1}$, b.w., p.o.) or $\mathrm{NaCl}(9 \%)$ for one hour ${ }^{a}$

\begin{tabular}{llll}
\hline Group & Rats number & Ulcer index $\left(\mathrm{mm}^{2}\right)$ & Protection percentage $(\%)$ \\
\hline Control & 10 & - & - \\
Aspirin & 10 & $62.75 \pm 2.28^{*}$ & 00 \\
Aspirin + ART-100 & 10 & $42.25 \pm 2.75 \#$ & 32.66 \\
Aspirin + ART-200 & 10 & $31.52 \pm 2.41 \#$ & 49.76 \\
Aspirin + ART-400 & 10 & $13.66 \pm 4.23 \#$ & 78.23 \\
Aspirin + FAM & 10 & $15.5 \pm 1.32 \#$ & 75.29 \\
Aspirin + CA & 10 & $09.25 \pm 1.54 \#$ & 85.25 \\
$a *: p<0.05$ compared to control group and $\#: p<0.05$ compared to aspirin group. & \\
\end{tabular}

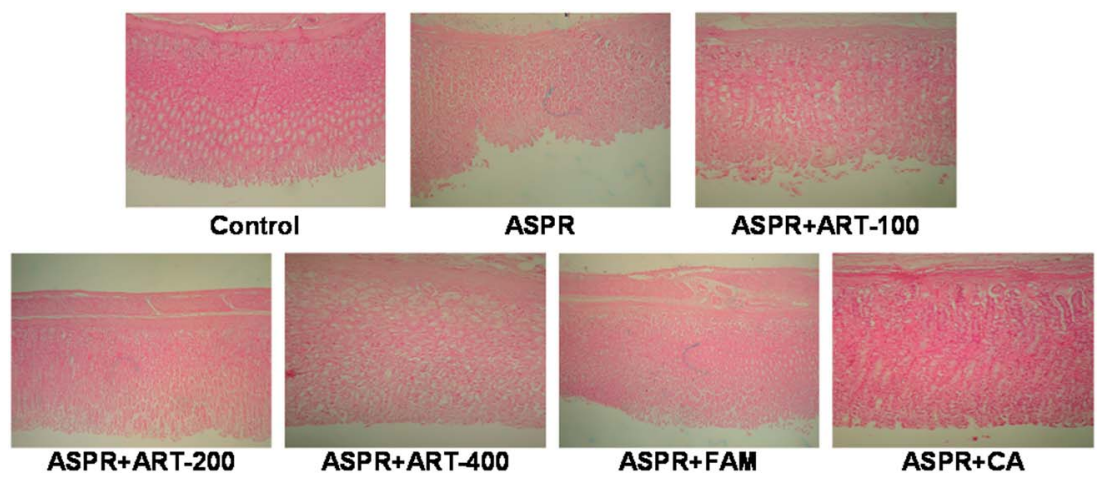

Fig. 4 Subacute effect of Artemisia campestris aqueous extract (ACAE), famotidine and caffeic acid on histological changes induced by aspirin in rats. Animals were pre-treated with various doses of ACAE (100, 200 and $400 \mathrm{mg} \mathrm{kg}^{-1}$, b.w., p.o.), famotidine (20 mg kg ${ }^{-1}$, b.w., p.o.), caffeic acid (50 $\mathrm{mg} \mathrm{kg}^{-1}$, b.w., p.o.) or bi-distilled water, challenged with a single oral administration of aspirin (300 mg kg ${ }^{-1}$, b.w., p.o.) or $\mathrm{NaCl}(9 \%)$ for one hour.

\subsection{Effects of ACAE on aspirin-induced gastric mucosa lipoperoxidation}

To investigate the implication of oxidative stress in the gastroprotective effect of Artemisia campestris, stomach mucosa was first assessed for MDA determination. We showed that aspirin administration significantly increased stomach mucosal MDA level. More importantly, ACAE pre-treatment significantly and dose-dependently reduced gatric lipoperoxidation induced by NSAIDs intoxication (Fig. 5). Lipoperoxidation was also corrected by famotidine and caffeic acid administration.

\subsection{Effects of ACAE on depletion of aspirin-induced mucosa antioxidant enzyme activities}

We also studied the gastric antioxidant enzyme activities (Fig. 6). As expected, aspirin treatment significantly decreased stomach mucosa antioxidant enzyme activities as SOD (A), CAT (B) and GPx (C). Pre-treatment with ACAE, famotidine or caffeic acid significantly reversed all the aspirin-induced reductions in antioxidant enzyme activities to near control in a dosedependent manner.

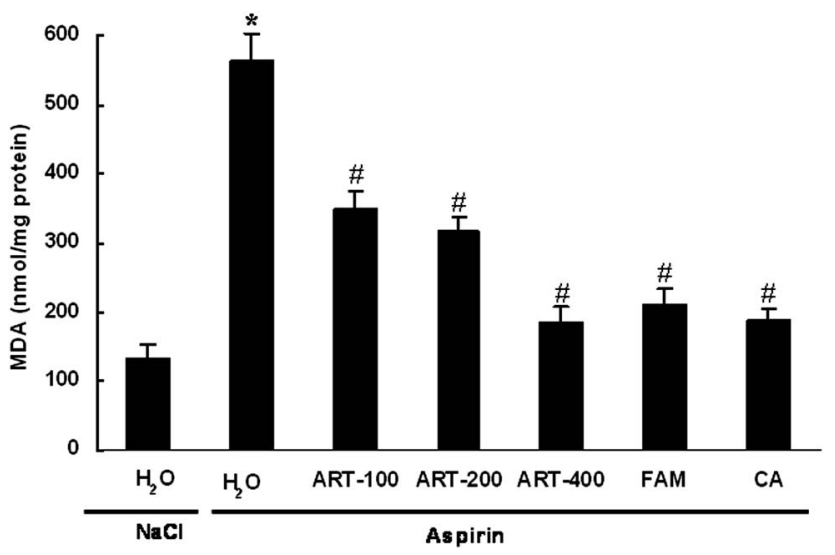

Fig. 5 Subacute effect of Artemisia campestris aqueous extract (ACAE), famotidine and caffeic acid on aspirin-induced changes in stomach mucosal MDA level in rats. Animals were pre-treated with various doses of ACAE (100, 200 and $400 \mathrm{mg} \mathrm{kg}^{-1}$, b.w., p.o.), famotidine (20 mg kg ${ }^{-1}$, b.w., p.o.), caffeic acid ( $50 \mathrm{mg} \mathrm{kg}^{-1}$, b.w., p.o.) or bidistilled water, challenged with a single oral administration of aspirin (300 $\mathrm{mg} \mathrm{kg}^{-1}$, b.w., p.o.) or $\mathrm{NaCl}(9 \%)$ for one hour. Assays were carried out in triplicate. *: $p<0.05$ compared to control group and \#: $p<0.05$ compared to aspirin group. 


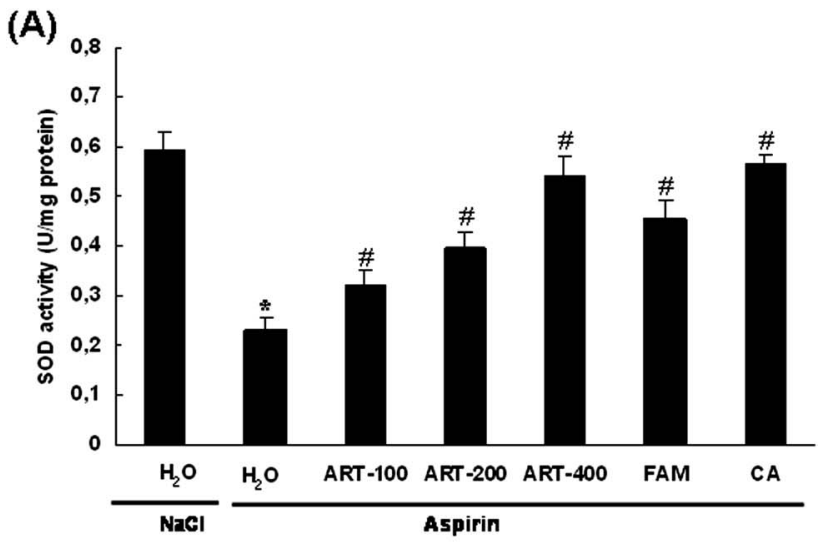

(B)

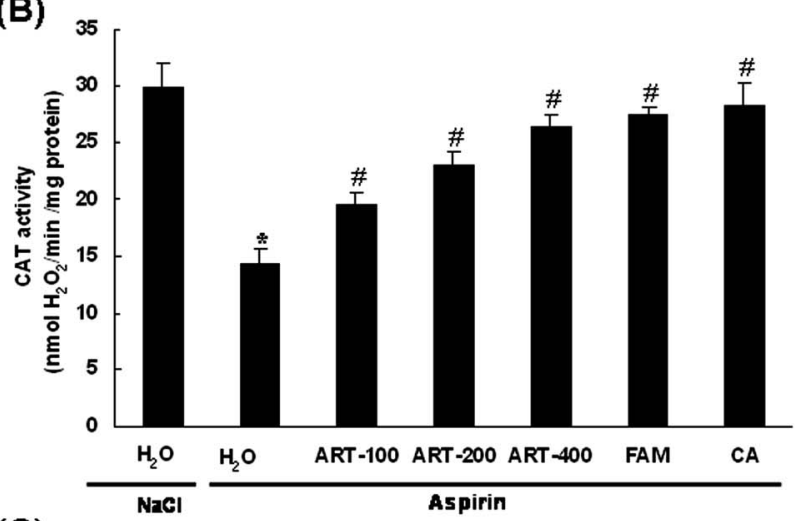

(C)

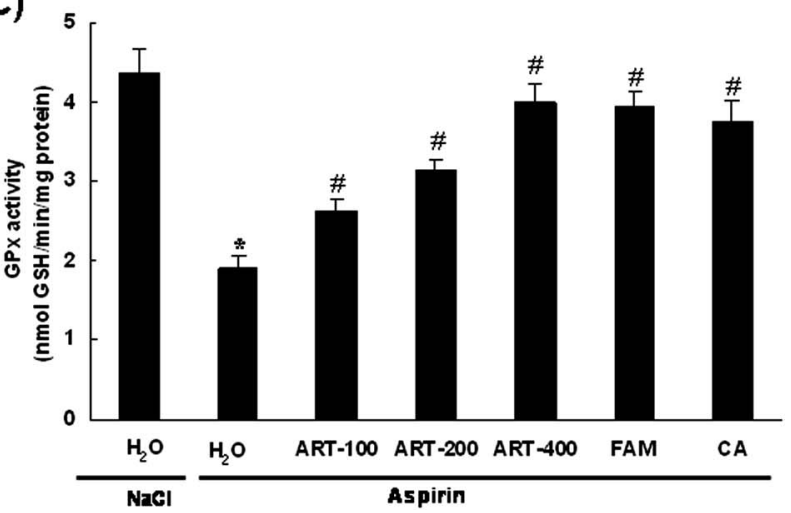

Fig. 6 Subacute effect of Artemisia campestris aqueous extract (ACAE), famotidine and caffeic acid on aspirin-induced changes in stomach mucosa antioxidant enzyme activities: SOD (A), CAT (B) and $\mathrm{GPx}(\mathrm{C})$ in rats. Animals were pre-treated with various doses of ACAE (100, 200 and $400 \mathrm{mg} \mathrm{kg}^{-1}$, b.w., p.o.), famotidine $\left(20 \mathrm{mg} \mathrm{kg}^{-1}\right.$, b.w., p.o.), caffeic acid $\left(50 \mathrm{mg} \mathrm{kg}^{-1}\right.$, b.w., p.o.) or bi-distilled water, challenged with a single oral administration of aspirin $\left(300 \mathrm{mg} \mathrm{kg}^{-1}\right.$, b.w., p.o.) or $\mathrm{NaCl}(9 \%)$ for one hour. Assays were carried out in triplicate. *: $p<0.05$ compared to control group and \#: $p<0.05$ compared to aspirin group.

3.8. Effects of ACAE on aspirin-induced changes in gastric mucosa -SH group's content

Moreover, we examined the effect of ACAE and aspirin treatment on sulfhydril levels. As expected, gastric mucosa injuries were accompanied by a significant decrease in $-\mathrm{SH}$ groups content. Subacute Artemisia campestris pre-treatment significantly and dose-dependently corrected the decrease in thiol

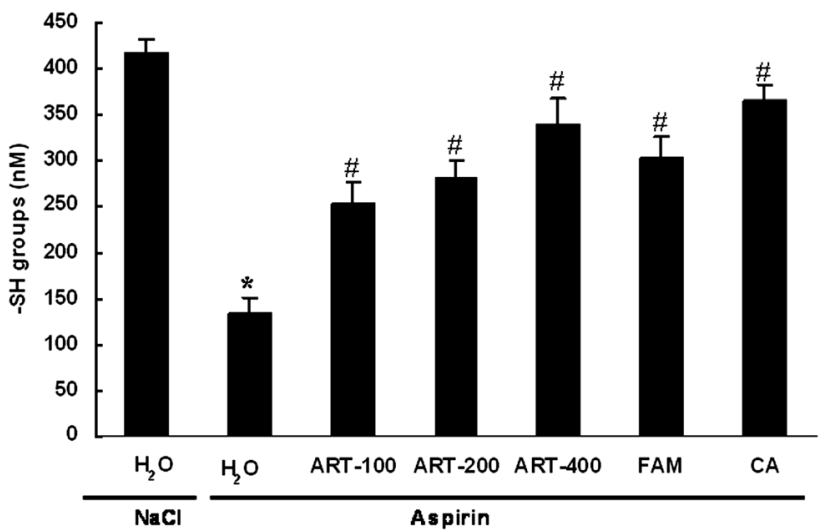

Fig. 7 Subacute effect of Artemisia campestris aqueous extract (ACAE), famotidine and caffeic acid on aspirin-induced changes in stomach mucosa $\mathrm{SH}-$ groups level in rats. Animals were pre-treated with various doses of $\operatorname{ACAE}\left(100,200\right.$ and $400 \mathrm{mg} \mathrm{kg}^{-1}$, b.w., p.o.), famotidine (20 $\mathrm{mg} \mathrm{kg}^{-1}$, b.w., p.o.), caffeic acid $\left(50 \mathrm{mg} \mathrm{kg}^{-1}\right.$, b.w., p.o.) or bi-distilled water, challenged with a single oral administration of aspirin (300 mg kg-1, b.w., p.o.) or $\mathrm{NaCl}(9 \%)$ for one hour. Assays were carried out in triplicate. *: $p<0.05$ compared to control group and \#: $p<0.05$ compared to aspirin group.

groups induced by aspirin administration. This effect was also significantly corrected by subacute famotidine and caffeic acid pre-treatment (Fig. 7).

\subsection{Effects of ACAE on aspirin-induced gastric mucosa elevation of iron, $\mathrm{H}_{2} \mathrm{O}_{2}$ and calcium}

We further examined the effect of aspirin and ACAE on intracellular mediators as hydrogen peroxide, free iron and calcium levels in gastric mucosa (Table 3). Aspirin per se significantly increased free iron, $\mathrm{H}_{2} \mathrm{O}_{2}$ and calcium levels. However, subacute pre-treatment with ACAE, famotidine or caffeic acid significantly reduced the deregulation of aspirin-induced intracellular mediators in a dose-dependent manner. ACAE alone had no considerable effects on these parameters.

\section{Discussion}

The present study was undertaken to investigate the protective effect of Artemisia campestris aqueous extract on aspirininduced gastric ulceration. We also investigated the implication of oxidative stress as well as some gastric mucosal defence mechanisms in this eventual gastroprotection.

A phytochemical study of the ACAE using HPLC-PDA-ESI-MS/ MS analysis allowed the identification of 11 phenolic compounds: chlorogenic acid, caffeic acid, isorhamnetin hexoside, 3,4-dicaffeoylquinic acid, 3,5-dicaffeoylquinic acid, 4,5-dicaffeoylquinic acid, quercetin-3-O-glucuronide, apigenin7-O-hexoside, apigenin-6-C-glucuronide-8- $C$-pentoside, kaempferol and apigenin. These molecules were previously reported in many plant extracts and are known for their antioxidant and gastroprotective properties. ${ }^{32}$ In this respect, the DPPH radicalscavenging assay was investigated. We showed that ACAE presents a higher scavenging capacity but lesser than that of 
Table 3 Subacute effect of Artemisia campestris aqueous extract (ACAE), famotidine and caffeic acid on aspirin-induced changes in stomach mucosa and plasma hydrogen peroxide, free iron and calcium levels in rats. Animals were pre-treated with various doses of ACAE (100, 200 and $400 \mathrm{mg} \mathrm{kg}^{-1}$, b.w., p.o.), famotidine (20 mg kg ${ }^{-1}$, b.w., p.o.), caffeic acid (50 mg kg ${ }^{-1}$, b.w., p.o.) or bi-distilled water, and were challenged with a single oral administration of aspirin $\left(300 \mathrm{mg} \mathrm{kg}^{-1}\right.$, b.w., p.o.) or $\mathrm{NaCl}(9 \%)$ for one hour. Assays were carried out in triplicate ${ }^{a}$

\begin{tabular}{|c|c|c|c|c|c|c|}
\hline \multirow[b]{2}{*}{ Group } & \multicolumn{2}{|l|}{ Hydrogen peroxide } & \multicolumn{2}{|l|}{ Free iron } & \multicolumn{2}{|l|}{ Calcium } \\
\hline & $\begin{array}{l}\text { Gastric mucosa (nmol } \\
\text { per mg per protein) }\end{array}$ & $\begin{array}{l}\text { Plasma } \\
\left(\mathrm{nmol} \mathrm{mL}^{-1}\right)\end{array}$ & $\begin{array}{l}\text { Gastric mucosa }(\mu \mathrm{mol} \\
\text { per mg per protein) }\end{array}$ & $\begin{array}{l}\text { Plasma } \\
\left(\mathrm{nmol} \mathrm{mL}^{-1}\right)\end{array}$ & $\begin{array}{l}\text { Gastric mucosa }(\mu \mathrm{mol} \\
\text { per mg per protein) }\end{array}$ & $\begin{array}{l}\text { Plasma } \\
\left(\mu \mathrm{mol} \mathrm{mL}^{-1}\right)\end{array}$ \\
\hline Control & $95.6 \pm 6.72$ & $956 \pm 35.58$ & $22.75 \pm 1.84$ & $0.97 \pm 0.04$ & $115.52 \pm 7.26$ & $1.68 \pm 0.1$ \\
\hline Aspirin & $309.5 \pm 14.59^{*}$ & $1800 \pm 113.73^{*}$ & $60.00 \pm 4.40^{*}$ & $1.23 \pm 0.04^{*}$ & $285.20 \pm 9.64^{*}$ & $2.78 \pm 0.08^{*}$ \\
\hline Aspirin + ART-100 & $159.2 \pm 18.57 \#$ & $1451.67 \pm 16.18 \#$ & $46.67 \pm 2.94 \#$ & $1.10 \pm 0.04 \#$ & $183.11 \pm 11.85 \#$ & $2.19 \pm 0.1 \#$ \\
\hline Aspirin + FAM & $108.5 \pm 16.07 \#$ & $1117.5 \pm 71.96 \#$ & $43.50 \pm 4.11 \#$ & $0.96 \pm 0.04 \#$ & $165.91 \pm 10.70 \#$ & $1.92 \pm 0.1 \#$ \\
\hline Aspirin + CA & $135.6 \pm 11.02 \#$ & $1003 \pm 53.35 \#$ & $30.75 \pm 4.14 \#$ & $0.96 \pm 0.04 \#$ & $213.20 \pm 12.72 \#$ & $2.09 \pm 0.09 \#$ \\
\hline
\end{tabular}

$a *: p<0.05$ compared to control group and \#: $p<0.05$ compared to aspirin group.

ascorbic acid used as reference molecule. The antioxidant capacity of ACAE is mainly related to the higher levels of polyphenols and flavonoids (data not shown). However, a positive correlation between phenolic compounds and antioxidant capacity is common in the majority of natural extracts. ${ }^{33,34}$

In vivo, we first showed that acute aspirin administration clearly induced macroscopic injuries, including hemorrhage and hyperemia, as well as histopatological changes such as erosive lesions. Synthetic non-steroidal anti-inflammatory drugs (NSAIDs), such as aspirin, causes mucosal damage by interfering with prostaglandin synthesis, increasing acid secretion and blocking $\mathrm{H}^{+}$diffusion.$^{35}$ Nevertheless, the key mechanism of NSAIDs-induced gastric ulceration is the irreversible and non-selective inhibition of cyclooxygenase activity, which interferes with the synthesis of prostaglandins. This triggers the effects derived from PG depletion, and shuttles the arachidonic acid metabolism toward the lipoxygenase pathway, increasing the formation of vasoconstrictor leukotrienes. ${ }^{36,37}$

Our data also showed that sub-acute pre-treatment with ACAE, famotidine or caffeic acid abolished all macroscopic and microscopic changes induced by aspirin intoxication in a doserelated manner. Concerning ACAE acute toxicity, we showed that the LD50 value was greater than $3200 \mathrm{mg} \mathrm{kg}^{-1}$ b.w. and neither mortality nor behavior impairment were observed during the observation period. However, aspirin-induced gastric ulceration has been previously shown to be attenuated by many plants extracts such as Chamaemelum nobile, ${ }^{38}$ Rubia cordifolia ${ }^{39}$ Allium sativum, ${ }^{40}$ Centaurium erythraea, ${ }^{41}$ Cucurbita pepo $^{42}$ as well as grape seed extract. ${ }^{9}$

Importantly, in the present study, we showed that acute aspirin administration induced an oxidative stress status in the gastric mucosa assessed by an increase in lipoperoxidation level as well as a depletion of antioxidant enzyme activities such as SOD, CAT and GPx. These data fully corroborated previous reports, indicating that NSAIDs-induced gastric mucosal injuries, including aspirin, are accompanied by an oxidative stress status. ${ }^{43-45}$
Aspirin, when used at the therapeutic level, is safe and broadly utilized as NSAIDs but higher doses or prolonged use of this drug may induce gastrointestinal erosions and apoptotic lesions. ${ }^{46}$ NSAIDs also exert other biological effects, including the generation of ROS and the inhibition of NF- $\mathrm{BB}-$ mediated signals. ${ }^{47}$ Excessive ROS production causes lipid membranes and protein attack as well as ultimately disrupting cellular integrity, leading to incontrollable oxidative stress status. ${ }^{48}$ Importantly, in the present work, we showed that Artemisia campestris pre-treatment protects against aspirin-induced oxidative stress in gastric mucosa. A. campestris has recently been proven to be rich in bioactive compounds such as polyophenols. ${ }^{13,15}$ These molecules are the primal source of the antioxidant ability of this plant by scavenging free radicals, such as hydroxyl radical $\left(\mathrm{OH}^{*}\right)$, which is the major cause of lipid peroxidation. ${ }^{49}$ Because of their antioxidant ability, A. campestris extrats were shown to have many beneficial health effects in vivo ${ }^{14-16}$ and in vitro. ${ }^{15}$ However, kaempferol, apigenin or its derivatives identified in the ACAE were previously presented as having both antiulcer and antioxidant properties. ${ }^{50,51}$ To the best of our knowledge, our report is the first to deal with the protective effect of $A$. campestris aqueous extract on acute aspirin-induced injuries in the rat gastric mucosa.

In this respect, ACAE has also been shown to protect against the decrease of thiol groups levels induced by aspirin treatment. It is well-known that sulfhydryls are in part involved in gastric cytoprotection..$^{52,53}$ However, sulfhydryls are known to maintain the integrity of mucosal barrier and scavenge free radicals formed due to the action of noxious agents. ${ }^{54}$ The capacity of aspirin to decrease the level of sulfhydryl groups was previously shown in gastric mucosa ${ }^{55}$ and liver..$^{56}$ The problem of NSAIDs, such as aspirin, effect on sulfur metabolism has already been an interesting domain of investigation. In this respect, it has been demonstrated that aspirin is effective in promoting increased sulphate incorporation into the bone-forming regions of the chick. ${ }^{57}$ However, it is tempting to speculate that aspirin and ACAE exert opposite effects on sulfhydryl groups in gastric mucosa. The same mechanism was previously described but for 
an EtOH-induced $\mathrm{SH}$-group level decrease using silymarin as a gastoprotective mediator. ${ }^{55}$

More interestingly, in the present work, we showed that $A$. campestris pre-treatment abolished acute aspirin-induced increases in $\mathrm{H}_{2} \mathrm{O}_{2}$, free iron and calcium levels in plasma and gastric mucosa. However, iron and $\mathrm{H}_{2} \mathrm{O}_{2}$ accumulation catalyzed the highly toxic hydroxyl radical $\left(\mathrm{OH}^{*}\right)$ production via the Fenton reaction, leading to membrane lipoperoxidation and enhancement of its permeability to calcium. ${ }^{\mathbf{5 8}}$

It is generally reported that oxidants can cause a rapid increase in cytoplasm calcium levels in various cell types. ${ }^{\mathbf{5 9 , 6 0}}$ This increase may be due to both the release of calcium from internal cellular organelles, such as the endoplasmic or sarcoplasmic reticulum, or its import from extracellular space across the plasma membrane. This function is dependent on calcium concentration and the involved oxidants. ${ }^{61}$ Indeed, high concentrations of hydrogen peroxide were previously shown to induce a cytosolic calcium increase accompanied by a reduction in extracellular levels. ${ }^{62}$ Thus, we can speculate that aspirin and ACAE exerted opposite effects on free iron and hydrogen peroxide leading to calcium homeostasis.

\section{Conclusion}

The results of the present study clearly indicate that A. campestris aqueous extract protected against aspirin-induced lesions in gastric mucosa. Our results also demonstrated that AEAC gastroprotection might be related, at least in part, to its antioxidant properties as well as to various gastric mucosal defence mechanisms, including the protection of gastric sulfhydryls and an opposite effect on some intracellular mediators such as free iron, hydrogen peroxide and calcium.

\section{Declaration of interest}

The authors alone are responsible for the contents of this paper.

\section{Abbreviations}

$\begin{array}{ll}\text { ACAE } & \text { Artemisia campestris aqueous extract } \\ \text { ART } & \text { Artemisia campestris } \\ \text { CA } & \text { Caffeic acid } \\ \text { CAT } & \text { Catalase } \\ \text { FAM } & \text { Famotidine } \\ \text { GPx } & \text { Glutathione peroxidase } \\ \mathrm{H}_{2} \mathrm{O}_{2} & \text { Hydrogen peroxide } \\ \text { MDA } & \text { Malondialdehyde } \\ \text { NSAIDs } & \text { Non-steroidal anti-inflammatory drugs } \\ \text { SOD } & \text { Superoxide dismutase } \\ \text { SH } & \text { Sulfhydryl }\end{array}$

\section{Acknowledgements}

Financial support from the Tunisian Ministry of Higher Education and Scientific Research is gratefully acknowledged. Financial disclosures: none declared.

\section{References}

1 G. B. Glavin and S. Szabo, Experimental gastric mucosal injury: laboratory models reveal mechanisms of pathogenesis and new therapeutic strategies, FASEB J., 1992, 6, 825-831.

2 C. Tasman-Jones, Pathogenesis of peptic ulcer disease and gastritis: importance of aggressive and cytoprotective factors, Scand. J. Gastroenterol., 1986, 22, 1-5.

3 K. Ramakrishnan and R. C. Salinas, Peptic ulcer disease, Am. Fam. Physician, 2007, 76, 1005-1012.

4 L. Laine, K. Takeuchi and A. Tarnawski, Gastric mucosal defense and cytoprotection: bench to bedside, Gastroenterology, 2008, 135, 41-60.

5 A. R. Dehpour, M. E. Zolfaghari, T. Samadian and Y. Vahedi, The protective effect of liquorice components and their derivatives against gastric ulcer induced by aspirin in rats, J. Pharm. Pharmacol., 1994, 46, 148-149.

6 I. Wiklund, Quality of life in arthritis patients using nonsteroidal anti-inflammatory drugs, Can. J. Gastroenterol., 1999, 13, 129-133.

7 A. Saggioro, V. Alvisi, A. Blasi, G. Dobrilla, A. Fioravant and R. Marcolongo, Misoprostol prevents NSAID-induced gastroduodenal lesions in patients with osteoarthritis and rheumatoid arthritis, Ital. J. Gastroenterol., 1991, 23, 119123.

8 A. R. Dehpour, M. E. Zolfaghari, T. Samadian, F. Kobarfard, M. Faizi and M. Assari, Antiulcer activities of liquorice and its derivatives in experimental gastric lesion induced by ibuprofen in rats, Int. J. Pharm., 1995, 119, 133-138.

9 V. M. Cuevas, Y. R. Calzado, Y. P. Guerra, A. O. Yera, S. J. Despaigne, R. M. Ferreiro and D. C. Quintana, Effects of grape seed extract, vitamin $\mathrm{C}$, and vitamin $\mathrm{E}$ on ethanoland aspirin-induced ulcers, Adv. Pharmacol. Sci., 2011, 2011, 740.

10 T. Pohle, T. Brzozowski and J. C. Becker, Role of reactive oxygen metabolites in aspirin-induced gastric damage in humans: gastroprotection by vitamin $\mathrm{C}$, Aliment. Pharmacol. Ther., 2001, 15, 677-687.

11 M. Ikeda, K. Nakabayashi, M. Shinkai, Y. Hara, T. Kizaki, S. Oh-ishi and H. Ohno, Supplementation of antioxidants prevents oxidative stress during a deep saturation dive, Tohoku J. Exp. Med., 2004, 203, 353-357.

12 C. A. Hiruma-Lima, J. S. Gracioso, W. Toma, A. B. Almeida, A. C. Paula and D. S. Brasil, Gastroprotective effect of aparisthman, a diterpene isolated from Aparisthmium cordatum on experimental gastric ulcer models in rats and mice, Phytomedicine., 2001, 8, 94-100.

13 A. Akrout, L. A. Gonzalez, H. El Jani and P. C. Madrid, Antioxidant and antitumor activities of Artemisia campestris and Thymelaea hirsuta from southern Tunisia, Food Chem. Toxicol., 2010, 49, 342-347.

14 M. Sefi, A. Troudi, F. B. Hamida, N. Soudani, T. Boudawara and N. Zeghal, Protective effects of Artemisia campestris upon fenthion-induced nephrotoxicity in adult rats and their progeny, Gen. Physiol. Biophys., 2013, 32, 577-588. 
15 Y. Aniya, M. Shimabukuro, M. Shimoji, M. Kohatsu, M. A. Gyamfi, C. Miyagi, D. Kunii, F. Takayama and T. Egashira, Antioxidant and hepatoprotective actions of the medicinal herb Artemisia campestris from the Okinawa Islands, Biol. Pharm. Bull., 2000, 23, 309-312.

16 M. Sefi, H. Fetoui, M. Makni and N. Zeghal, Mitigating effects of antioxidant properties of Artemisia campestris leaf extract on hyperlipidemia, advanced glycation end products and oxidative stress in alloxan-induced diabetic rats, Food Chem. Toxicol., 2010, 48, 1986-1993.

17 A. Houicher, E. Kuley, B. Bendeddouche and F. Ozogul, Effect of Mentha spicata L. and Artemisia campestris extracts on the shelf life and quality of vacuum-packed refrigerated sardine (Sardina pilchardus) fillets, J. Food Prot., 2013, 76, 1719-1725.

18 T. Carbonara, R. Pascale, M. P. Argentieri, P. Papadia, F. P. Fanizzi, L. Villanova and P. Avato, Phytochemical analysis of a herbal tea from Artemisia annua L, J. Pharm. Biomed. Anal., 2012, 62, 79-86.

19 M. N. Clifford, S. Knight and N. Kuhnert, Discriminating between the six isomers of dicaffeoylquinic acid by LC-MSn, J. Agric. Food Chem., 2005, 53, 3821-3832.

20 J. Han, M. Ye, X. Qiao, M. Xu, B. R. Wong and D. A. Guo, Characterisation of phenolic compounds in the Chinese herbal drug Artemisia annua by liquid chromatography coupled to electrospray ionisation mass spectrometry, $J$. Pharm. Biomed. Anal., 2008, 47, 516-525.

21 S. Gouveia and P. C. Castilho, Characterisation of phenolic acid derivatives and flavonoids from different morphological parts of Helichrysum obconicum by a RPHPLC-DAD-(-)-ESI-MSn method, Food Chem., 2011, 129, 333-344.

22 I. Grzegorczyk, A. Matkowski and H. Wysokinska, Antioxidant activity of extracts from in vitro cultures of Salvia officinalis L, Food Chem., 2007, 104, 536-541.

$23 \mathrm{H}$. H. Draper and M. Hadley, Malondialdehyde determination as index of lipid peroxidation, Methods Enzymol., 1990, 186, 421-431.

24 H. P. Misra and I. Fridovich, The role of superoxide anion in autoxidation of epinephrine and a simple assay for superoxide dismutase, J. Biol. Chem., 1972, 247, 3170-3175.

25 H. Aebi, Catalase in vitro, Methods Enzymol., 1984, 105, 121126.

26 L. Flohé and W. A. Günzler, Assays of glutathione peroxidase, Methods Enzymol., 1984, 105, 114-121.

27 G. L. Ellman, Tissue sulfhydryl groups, Arch. Biochem. Biophys., 1959, 82, 70-77.

28 B. Dingeon, J. P. Ferry and A. Roullet, Automatic assay of blood sugar by Trinder's method, Ann. Biol. Clin., 1975, 33, 3-13.

29 A. Leardi, M. Caraglia, C. Selleri, S. Pepe, C. Pizzi, R. Notaro, A. Fabbrocini, D. S. Lorenzo, M. Musicò, A. Abbruzzese, A. R. Bianco and P. Tagliaferri, Desferioxamine increases iron depletion and apoptosis induced by ara-C of human myeloid leukaemic cells, Br. J. Haematol., 1998, 102, 746752.
$30 \mathrm{~J}$. Stern and W. H. Lewis, The colorimetric estimation of calcium in serum with ocresolphthalein complexone, Clin. Chim. Acta, 1957, 2, 576-580.

31 E. F. Hartree, Determination of protein: a modification of the Lowry method that gives a linear photometric response, Anal. Biochem., 1972, 48, 422-427.

32 P. A. Rodrigues, S. M. Morais, C. M. Souza, D. V. Magalhães, I. G. Vieira, G. M. Andrade, V. S. Rao and F. A. Santos, Gastroprotective effect of Byrsonima sericea DC leaf extract against ethanol-induced gastric injury and its possible mechanisms of action, An. Acad. Bras. Cienc., 2012, 84, 113-122.

33 S. U. Chon, B. U. Heo, Y. S. Park, D. K. Kim and S. Gorinstein, Total phenolics level, antioxidant activities and cytotoxicity of young sprouts of some traditional Korean salad plants, Plant Foods Hum. Nutr., 2009, 64, 25-31.

34 İ. Hamad, Ö. Erol-Dayi, M. Pekmez, E. Önay-Uçar and N. Arda, Antioxidant and cytotoxic activities of Aphanes arvensis extracts, Plant Foods Hum. Nutr., 2010, 65, 44-49.

35 C. V. Roa, R. N. Maiti and R. K. Goel, Effect of mid irritant on gastric mucosal offensive and defensive factors. Med, $J$. Physiol. Pharmacol., 1999, 44, 185-191.

36 B. J. Whittle, Gastrointestinal effects of nonsteroidal antiinflammatory drugs, Fundam. Clin. Pharmacol., 2003, 17(3), 301-313.

37 M. Jainu and C. S. Devi, Gastroprotective action of Cissus quadrangularis extract against NSAID induced gastric ulcer: role of proinflammatory cytokines and oxidative damage, Chem.-Biol. Interact., 2006, 161, 262-270.

38 H. Nomiri, S. J. Aldavood and R. Sedaghat, Comparative efficacy of chamomile against omeprazole in aspirininduced gastric ulcer in rats, Comp. Clin. Pathol., 2014, 23, 673-678.

39 R. S. Deoda, D. Kumar and S. S. Bhujbal, Gastroprotective Effect of Rubia cordifolia Linn. on Aspirin Plus PylorusLigated Ulcer, J. Evidence-Based Complementary Altern. Med., 2011, 2011, 541-624.

40 M. A. Mabrouk, F. I. Nnawodu, Y. Tanko, F. Dawud and A. Mohammed, Effect of Aqueous Garlic (Ag) Extract on Aspirin Induced Gastric Mucosal Lesion in Albino Wistar Rats, J. Biol. Sci., 2009, 1, 15-19.

41 Y. Tuluce, H. Ozkol, I. Koyuncu and H. Ine, Gastroprotective effect of small centaury (Centaurium erythraea L) on aspirininduced gastric damage in rats, Toxicol. Ind. Health, 2011, 27, 760-768.

42 S. Sarkar and D. Buha, Effect of ripe fruit pulp extract of Cucurbita pepo Linn. in aspirin induced gastric and duodenal ulcer in rats, Indian J. Exp. Biol., 2008, 46, 639-645.

43 M. Jainu, V. Mohan and S. Devi, Protective effect of Cissus quadrangularis on neutrophil mediated tissue injury induced by aspirin in rats, J. Ethnopharmacol., 2006, 104, 302-305.

44 L. Liu, J. Cui, C. J. Song, J. S. Bian, A. Sparatore, P. D. Soldato, X. Y. Wang and C. D. Yan, H(2)S-releasing aspirin protects against aspirin-induced gastric injury via reducing oxidative stress, PLoS One, 2012, 7, 46301. 
45 J. Y. Zhang, Q. F. Wu, Y. Wan, S. D. Song, J. Xu, X. S. Xu, H. L. Chang, M. H. Tai, Y. F. Dong and C. Liu, Protective role of hydrogen-rich water on aspirin-induced gastric mucosal damage in rats, World J. Gastroenterol., 2014, 20, 1614-1622.

46 N. R. Jana, NSAIDs and apoptosis, Cell. Mol. Life Sci., 2008, 65, 1295-1301.

47 M. Adachi, H. Sakamoto, R. Kawamura, W. Wang, K. Imai and Y. Shinomura, Nonsteroidal anti-inflammatory drugs and oxidative stress in cancer cells, Histol. Histopathol., 2007, 22, 437-442.

48 L. Gaté, J. Paul, G. N. Ba, K. D. Tew and H. Tapiero, Oxidative stress induced in pathologies: the role of antioxidants, Biomed. Pharmacother., 1999, 53, 169-180.

49 D. A. Kogiannou, N. Kalogeropoulos, P. Kefalas, M. G. Polissiou and A. C. Kaliora, Herbal infusions; their phenolic profile, antioxidant and anti-inflammatory effects in HT29 and PC3 cells, Food Chem. Toxicol., 2013, 61, 152159.

50 R. K. Goel, V. B. Pandey, S. P. Dwivedi and Y. V. Rao, Antiinflammatory and antiulcer effects of kaempferol, a flavone, isolated from Rhamnus procumbens, Indian J. Exp. Biol., 1988, 26, 121-124.

51 A. S. Awaad, N. A. Al-Jaber, J. E. Moses, R. M. El-Meligy and M. E. Zain, Antiulcerogenic activities of the extracts and isolated flavonoids of Euphorbia cuneata Vahl, Phytother. Res., 2013, 27, 126-130.

52 O. Strubelt and R. Hoppenkamps, Relations between gastric glutathione and the ulcerogenic action of non-steroidal antiinflammatory drugs, Arch. Int. Pharmacodyn. Ther., 1983, 262, 268-278.

53 S. Szabo, Role of sulfhydryls and early vascular lesions in gastric mucosal injury, Acta Physiol. Hung., 1984, 64, 203214.
54 S. Szabo and P. Vattay, Experimental gastric and duodenal ulcers. Advances in pathogenesis, Clin. Gastroenterol., 1990, 19, 67-85.

55 J. H. Shin, C. W. Lee, S. J. Oh, J. Yun, K. Lee, S. K. Park, H. M. Kim, S. B. Han, Y. Kim, H. C. Kim and J. S. Kang, Protective effect of silymarin against ethanol-induced gastritis in rats: role of sulfhydryls, nitric oxide and gastric sensory afferents, Food Chem. Toxicol., 2013, 55, 353-357.

56 A. Bilska, M. Iciek, I. Kwiecień, K. Kaniecki, M. Paliborek, E. Somogyi, J. Piotrowska, B. Wiliński, M. Góralska, Z. Srebro and L. Włodek, Effects of aspirin on the levels of hydrogen sulfide and sulfane sulfur in mouse tissues, Pharmacol. Rep., 2010, 62, 304-310.

57 R. P. Dowdy and F. H. Nielsen, Effect of histidine, histamine, and aspirin on sulfur-35 metabolism in zinc-deficient chick bone, J. Nutr., 1972, 102, 529-534.

$58 \mathrm{~L}$. W. Powell, The role of alcoholism in hepatic iron storage disease, Ann. N. Y. Acad. Sci., 1975, 252, 124-134.

59 T. A. Rooney, D. C. Renard, E. J. Sass and A. P. Thomas, Oscillatory cytosolic calcium waves independent of stimulated inositol 1,4,5-trisphosphate formation in hepatocytes, J. Biol. Chem., 1991, 266, 12272-12282.

$60 \mathrm{H}$. Wang and J. A. Joseph, Mechanisms of hydrogen peroxide-induced calcium dysregulation in PC12 cells, Free Radical Biol. Med., 2000, 28, 1222-1231.

61 K. Bielefeldt, C. A. Whiteis, R. V. Sharma, F. M. Abboud and J. L. Conklin, Reactive oxygen species and calcium homeostasis in cultured human intestinal smooth muscle cells, Am. J. Physiol., 1997, 272, 1439-1450.

62 A. Roveri, M. Coassin, M. Maiorino, A. Zamburlini, F. T. van Amsterdam, E. Ratti and F. Ursini, Effect of hydrogen peroxide on calcium homeostasis in smooth muscle cells, Arch. Biochem. Biophys., 1992, 297, 265-270. 